\title{
College Students' Usage of and Preferences for Print and Electronic Textbooks
}

\author{
https://doi.org/10.3991/ijet.v14i07.9871
}

\author{
Amjad Abuloum ( $\left.{ }^{\bowtie}\right)$, Adnan Farah, Esra Kaskaloglu, Abduyah Yaakub \\ University of Bahrain, Zallaq, Bahrain \\ aabuloum@uob.edu.bh
}

\begin{abstract}
Although print textbooks have been central for schooling for more than two centuries, electronic textbooks (e-textbooks) are steadily growing in popularity among students at all levels of education. This sharp growth has escalated the need for further research to enable a better understanding of the changing patterns of students' usage of print and electronic media. The study explores college students' usage of and preference for print and electronic textbooks in Bahrain Teachers' College, in Bahrain. The sample of the study consisted of 271 undergraduate students selected from courses that utilized both formats of textbook as clearly indicated in their syllabi. Descriptive analyses were used to analyze data collected. Results indicate that regardless of textbook format, the highest percentage of students use their textbooks only when their instructors require them to do so. For print textbooks, results show that the highest percentage of students spend between 1 to 3 hours a week on reading. However, for e-textbooks, the highest percentage of students spend only less than 1 hour per week on reading. An interesting finding for this study is that compared to print textbooks, e-textbooks gain a higher percentage of students' usage when it comes to spending higher numbers of hours of reading per week. The study affirms that students are in general positive to the use of electronic format but still show a preference for print format as the best medium for academic study. Lastly, the study uncovers reasonable findings as to why students prefer one textbook format over the other.
\end{abstract}

Keywords-Electronic textbooks, print textbooks, college students, textbook preference, Bahrain Teachers' College

\section{Introduction}

A textbook is a book used as a standard work for formal study of a specific subject [41]. By collecting huge amounts of facts from a wide spectrum of sources, textbooks are the standard platform of knowledge for students [6]. They are also integral learning tools that help in explaining various concepts and terms [24]. In fact, textbooks can be used to guide students when analyzing and solving problems in different areas of study [23]. And by aiding teaching and learning, textbooks can also help students make connections across the disciplines. Therefore, textbooks largely affect what is taught and what students learn [48; 52]. 
According to Simon \& Garcia-Belmar [47], the dramatic advancement in technology has undeniably brought innovations that can play a significant role in reshaping teaching and learning practices. These innovations have provided students access to much more information than has been previously available. They have also affected the manner in which students interact with materials. As an innovation, electronic books (or simply e-books) have been a viable format since late 1990s.

Wang [55] defines the e-book as a book published in a digital format, transferable via the Internet, and can be accessed and read on a portable device, such as a laptop, a smartphone, an eBook reader, a tablet or on a desktop computer. This digital format initially started as PDF files or a set of HyperText Markup Language (HTML) pages. New features, such as built-in dictionaries and pronunciations guides, audio, video, animations, interactive simulations, and live experiments were then added to facilitate the content understanding of e-books $[18 ; 28 ; 35 ; 39]$. Nowadays, other e-book digital formats, such as EPUB, AZW, RFT, IBA, LIT, ODF and MOBI, are gaining popularity among readers.

Electronic textbooks (or e-textbooks) are e-books that contain educational materials and functions, and are used for educational purposes [29]. Some of these educational purposes, however, require that the design of electronic textbooks be interactive, collaborative, and differ for students of different learning abilities. Therefore, electronic textbooks support authentic learning by incorporating collaborative tools such as peer review, sharing functionality, and content creation $[10 ; 17 ; 20 ; 34]$. According to Rockinson-Szapkiw et al. [43], digital course materials included in electronic textbooks have more interactive tools that support student learning inside and outside the classroom.

Johnston et al. [26] stated that while print is at present the dominant format of textbooks, the rising condition is supporting a move toward electronic textbooks. They also went on to say that electronic textbooks are a strong competitor for print textbooks despite the convenience and familiarity of the latter to learners. In a recent study, Kouis and Konstantinou [28] revealed that more than 62.5 percent of the participating students believed that electronic textbooks would be the primary format for textbooks in the near future. Similarly, Hendricks [22] affirmed that with the significant increase in the quality and availability of electronic textbooks, future generations of students are expected to use them in all levels of education. According to Lee, Messom, and Yau [30], electronic textbooks "will potentially replace existing paperbased textbooks in the school curriculum" (p. 32).

Baker-Eveleth and Stone [5] asserted that the use of digital book format in education is a trend that will not disappear in the short term. Since this trend is heavily and constantly supported by the technological and publishing industries [33], e-books or e-textbooks are continuously being updated to improve their features and functionality for a pleasant student experience [37]. Unfortunately, in spite of this, the adoption of electronic textbooks by students has been surprisingly slow $[8 ; 19 ; 38 ; 57]$ and has not yet reached an acceptable level [49]. Therefore, more time and more research are needed to better understand and evaluate this trend and its implications in education.

The purpose of this study is to assess the experience of college students regarding their usage of and preference for two textbook formats, electronic and print. The study 
also looked at the reasons for which students expressed their preference for one textbook format over the other. The understanding obtained from this study can provide some important guidelines on how to enhance the successful adoption of electronic textbooks in university education. The study was guided by the following research questions:

- How frequently do students use their print and electronic textbooks?

- How many hours a week do students usually spend on reading their print and electronic textbooks?

- What is students' preference for textbook format?

- What are the reasons for students' preference of textbook format?

\subsection{Print vs electronic: Usage and preference}

Literature has been robust in showing that the usage of electronic textbooks and other electronic resources in education is growing in popularity $[13 ; 27 ; 40 ; 53 ; 57$; 45; 51]. According to Walton [53], many academic libraries reported that the rates of use of electronic books are equal to or in some cases great than those of print books.

In a comprehensive study, Nicholas et al. [40] investigated the electronic book usage and perceptions in more than 120 universities in the UK. Based on the analysis of 22,437 survey responses, the study showed that the electronic book penetration is very strong. Around $62 \%$ of students were found to be using electronic books. The researchers concluded that "the e-book revolution has already happened but clearly it has someway to go" (p. 333).

Levine-Clark [31] carried out a study on the usage of electronic books by all students, faculty and staff at the University of Denver. The results demonstrated that electronic books were used by about half of the campus community. About $68 \%$ of faculty, $57 \%$ of undergraduates and $64 \%$ of postgraduates used them occasionally. Generally, of the 1,116 people responded to the survey, $28 \%$ used electronic books one time only, $62 \%$ thought that they used them occasionally, and $10 \%$ believed that they used them frequently. Similar results were obtained by Rowlands et al. [42] who showed that about half of the 2,067 participants did use electronic books. Along the same lines, the results of the study conducted by Anuadha and Usha [4] indicated that $59.4 \%$ of the participated students from the Indian Institute of Science had used electronic books at some time.

In a national study, Cumaoglu et al. [11] examined the electronic book versus print material usage preferences of 222 students from 36 different universities in Turkey. Regarding print materials, the study revealed that around $50 \%$ of students read course books (i.e. textbooks). Results related to the frequency of reading print books, the study found that $68.3 \%$ of students read at least one book in a week, $19.9 \%$ read at least one book in a month, 7.7\% read at least one book in 6 months, and $2.7 \%$ read at least one book in a year. Concerning electronic books, the findings revealed that while $62.4 \%$ of students are e-book readers, $37.6 \%$ never read e-books. The study also manifested that the top-rated advantages of e-books over print materials were as fol- 
lows: ease of access (68.1\% rating), ease of archive (58\%), and ease of use (31.2\% rating).

Foasberg [16] conducted a qualitative study on university students' reading habits with regard to print and electronic formats. The results asserted that while all students utilized both formats, students used the print resources more frequently for lengthy reading.

Khalid's [27] study analyzed college students' preference for electronic and print textbooks. The study focused on the reasons behind students' preference. A total of 443 responses were received and analyzed. Results showed that the majority of students preferred the print version of textbooks because of readability, ease of use, and portability. However, students who preferred electronic textbooks were inclined by their low cost, portability, and ease of access. In the same line of thought, Millar and Schrier [36] reported that the primary reason students preferred print to electronic textbooks was that "printed textbooks were more convenient than electronic textbooks" (p. 182). In other words, reading from print textbooks does not require any devices or equipment. Another interesting reason for preferring print textbooks was brought up by Dobler's [15] study, in which participants' responses indicated that the ability to physically touch the pages when making notes and highlighting text is extremely important for kinesthetic learners. One last exciting reason for preferring print to electronic textbooks was emphasized by a number of researchers $[2 ; 25 ; 32]$, who declared that people retain more of what they read in print. This is likely because of the multi-sensory experience explained in the texture and smell of the paper. Regarding the preference for electronic over print textbooks, research studies reported a number of reasons, such as ease of transport, accessibility, ease of navigation, educational support, searching, availability, currency of information, and cost savings [1; $14 ; 44 ; 50]$.

Another study [21] explored the usage and preference of print and electronic resources among students and faculties of a university college. The results revealed that $30 \%$ of students preferred print materials only, $5 \%$ preferred e-resources only, and $65 \%$ preferred both. Regarding the frequency of use, the results showed that $5 \%$ of students used print material rarely, $40 \%$ used print material daily, $37.5 \%$ used print material weekly, and $22.5 \%$ used print material monthly. For e-resources, the results showed that $22.5 \%$ of students used e-resources rarely, $37.5 \%$ used e-resources daily, $30 \%$ used e-resources weekly, and $10 \%$ used e-resources monthly. A similar result regarding the frequency of use of e-resources has been achieved by Chiu (2017), who stated that electronic textbooks (one kind of e-resources) are used more on a daily basis when available in schools.

Recently, Adeyinka et al. [3] conducted a study to examine perception and usage pattern of electronic books among students of five universities in Nigeria. The study findings indicated that the entire sample (175 students, 100\%) used electronic books. The study also showed that while $52 \%$ of students preferred print to electronic books, $48 \%$ preferred electronic to print books.

In summary, our review of literature shows that although e-books are believed to replace print books, students at present continue to indicate a preference for the hardcover book. Our review also revealed a comparable preference for e-books in most 
studies. Furthermore, it has been evident that as e-books continue to evolve, they become more widely accepted among students. Therefore, students' preference for textbook formats may change.

\section{$2 \quad$ Methodology}

\subsection{Participants}

The sample of this study consisted of 271 undergraduate students (36 males $13.3 \%$, and 235 females $86.7 \%$ ). In order to have enough representation for all year level and specialization, participants were chosen based on purposive sampling, non-random sampling of the target population. Table 1 describes the student sample as related to different variables.

Table 1. Sample distribution based on gender, year of study, CGPA and specialization

\begin{tabular}{|c|c|c|}
\hline & Frequency & Percentage \\
\hline \multicolumn{3}{|c|}{ Gender } \\
\hline Male & 36 & 13.3 \\
\hline Female & 235 & 86.7 \\
\hline \multicolumn{3}{|c|}{ Year of Study } \\
\hline Year One & 57 & 21.0 \\
\hline Year Two & 65 & 24.0 \\
\hline Year Three & 95 & 35.1 \\
\hline Year Four & 54 & 19.9 \\
\hline \multicolumn{3}{|c|}{$C G P A$} \\
\hline Less than 2.00 & 1 & 0.4 \\
\hline $2.00-2.49$ & 49 & 18.0 \\
\hline $2.50-2.99$ & 92 & 33.9 \\
\hline $3.00-3.49$ & 88 & 32.6 \\
\hline $3.50-4.00$ & 41 & 15.1 \\
\hline \multicolumn{3}{|c|}{ Specialization } \\
\hline Cycle One & 67 & 24.7 \\
\hline Arabic and Islamic Studies & 66 & 24.3 \\
\hline Math and Science & 53 & 19.6 \\
\hline English & 85 & 31.4 \\
\hline
\end{tabular}

\subsection{Data collection instrument}

A self-administered survey questionnaire was used to collect the data for the study. The research survey questionnaire was specially designed for the purpose of this study. The questionnaire consisted of two sections. While the first section contained items related to the demographics of students participating in the study, the second one consisted of items evaluated on a 5-point Likert scale and several multiple-choice questions. The second section was meant to answer the research questions by investigating students' usage of and preference for print and electronic textbooks. 
To maintain the internal validity of a questionnaire, the first draft of the questionnaire was piloted. Twenty-five students from different specialization and year level took part in this pilot testing. Students were asked to check for any difficulty in answering the questions and to suggest alternative paraphrases to simplify complicated statements. Comments and suggestions were noted from the participants at this phase, and the draft questionnaire was revised. Pilot participants were excluded from the main study.

The internal consistency reliability estimate for the questionnaire was assessed with Cronbach Alpha. The alpha value was found to be (0.83), suggesting a reliable instrument for the purpose of the study. In addition, test-retest reliability over a twoweek period ranged from $(0.80)$ to $(0.84)$ for the questionnaire.

\subsection{Data analysis}

Out of 300 questionnaires distributed, 280 were retrieved. Nine (9) questionnaires were not counted due to missing data. Therefore, the total valid questionnaires that were included in the statistical analysis were 271. Data was analyzed using SPSS software. Means, standard deviations, and frequencies were calculated to help in providing answers for the research questions.

\section{$3 \quad$ Findings}

As mentioned earlier, this study was conducted to explore college students' experience with print and electronic textbooks in support of courses. Four research questions were formulated to guide the study. Findings are next presented according to these research questions.

\subsection{How frequently do students use their print and electronic textbooks?}

Regarding the first research question, Table 2 displays a summary of students' responses to the question "How frequently do you use your print textbooks?" The same responses were bar graphed in Figure 1.

Table 2. Students' Responses to "How frequently do you use your print textbooks?"

\begin{tabular}{|l|c|c|}
\hline & Frequency & Percent \\
\hline Regularly & 59 & 21.8 \\
\hline When Required by instructor & 154 & 56.8 \\
\hline Rarely & 37 & 13.7 \\
\hline Never Used & 21 & 7.7 \\
\hline Total & 271 & 100 \\
\hline
\end{tabular}




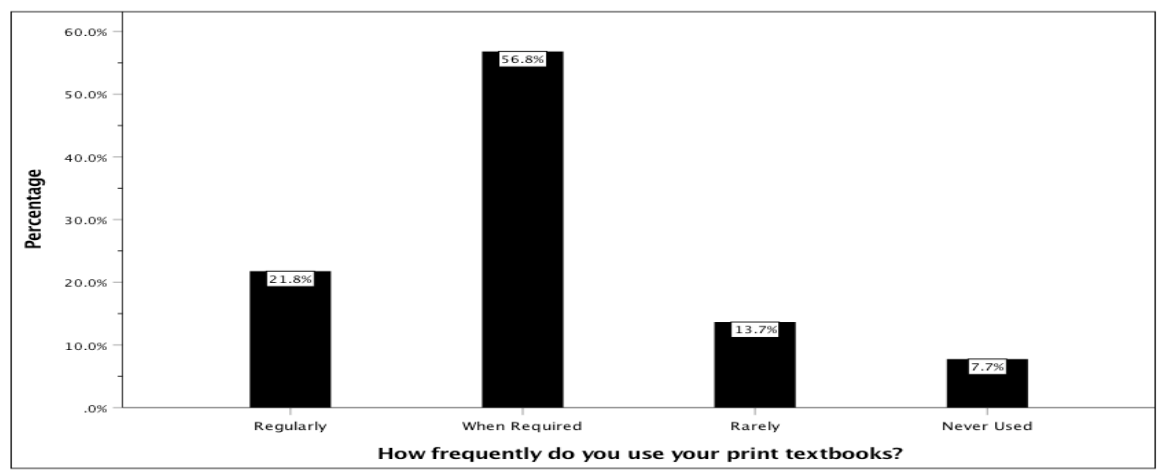

Fig. 1. Bar graph displaying Students' Responses to "How frequently do you use your print textbooks?"

Based on the above results, around $57 \%$ of the participating students were using print textbooks only when they were required by their instructors. It is worth to notice that around $22 \%$ (59 students) were using their print textbooks regularly.

Regarding electronic textbooks, students were asked to respond to the question "How frequently do you use your electronic textbooks?" A summary of the results is displayed in Table 3 and bar graphed in Figure 2.

Table 3. Students' Responses to "How frequently do you use your electronic textbooks?"

\begin{tabular}{|l|c|c|}
\hline & Frequency & Percent \\
\hline Regularly & 55 & 20.3 \\
\hline When Required by instructor & 137 & 50.5 \\
\hline Rarely & 43 & 15.9 \\
\hline Never Used & 36 & 13.3 \\
\hline Total & 271 & 100 \\
\hline
\end{tabular}

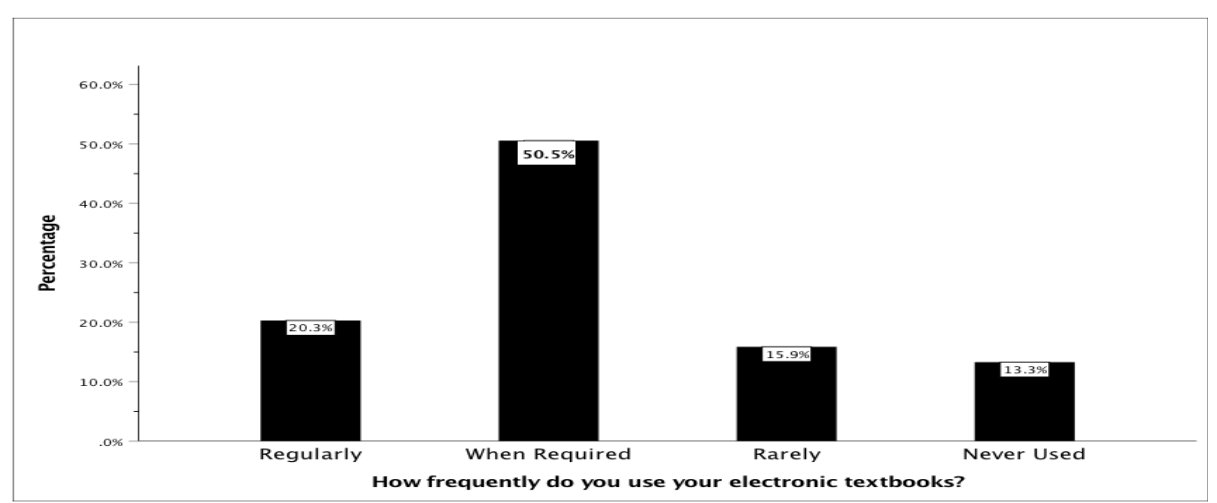

Fig. 2. Bar graph displaying students' responses to "How frequently do you use your electronic textbooks?" 
As shown above, the results indicated that around half of the sample $(50.5 \%, 137$ students) were using electronic textbooks only when they were required by their instructors. The results also showed that around $20 \%$ of the students were using their electronic textbooks regularly.

\subsection{How many hours a week do students usually spend on reading their print and electronic textbooks?}

The second research question was concerned with the number of hours students usually spend on reading their print and electronic textbooks. Regarding print textbooks, students reported the results shown in Table 4. These results were used to create the bar graph displayed in Figure 3.

Table 4. Students' Responses to "How many hours a week do you usually spend reading your print textbooks?'

\begin{tabular}{|l|c|c|}
\hline & Frequency & Percent \\
\hline More than 3 hours a Week & 30 & 11.1 \\
\hline Between 1 to 3 hours a Week & 109 & 40.2 \\
\hline Less than 1 hour a Week & 69 & 25.5 \\
\hline I do not read textbooks & 63 & 23.2 \\
\hline Total & 271 & 100 \\
\hline
\end{tabular}

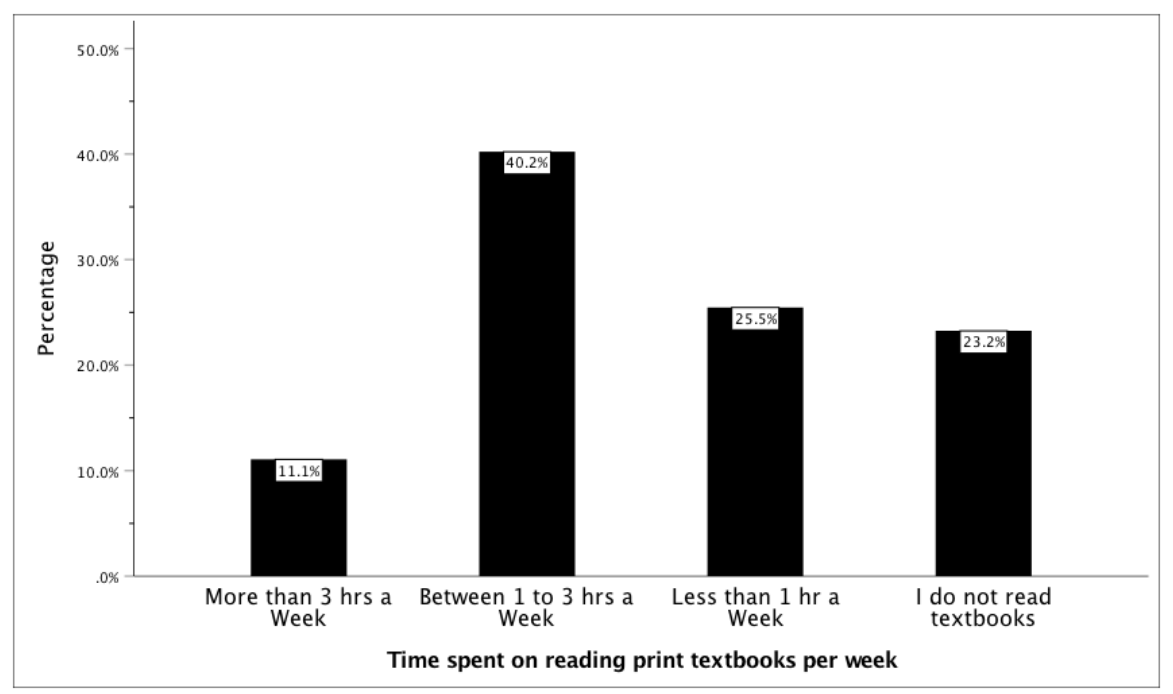

Fig. 3. Bar graph displaying Students' Responses to "How many hours a week do you usually spend reading your print textbooks?"

The results indicated that around $40 \%$ of the participating students were spending 1-3 hours per week reading their print textbooks. However, only $11 \%$ of these stu- 
dents were spending more than 3 hours per week reading print textbooks. The results also indicated that around $23 \%$ of the students were not reading their print textbooks at all.

Regarding electronic textbooks, the results obtained from the analysis of students' responses are displayed in Table 5. A bar graph depicting these results is shown in Figure 4.

Table 5. Students' Responses to "How many hours a week do you usually spend reading your electronic textbooks?"

\begin{tabular}{|l|c|c|}
\hline & Frequency & Percent \\
\hline More than 3 hours a Week & 33 & 12.2 \\
\hline Between 1 to 3 hours a Week & 66 & 24.4 \\
\hline Less than 1 hour a Week & 89 & 32.8 \\
\hline I do not read e-books & 83 & 30.6 \\
\hline Total & 271 & 100 \\
\hline
\end{tabular}

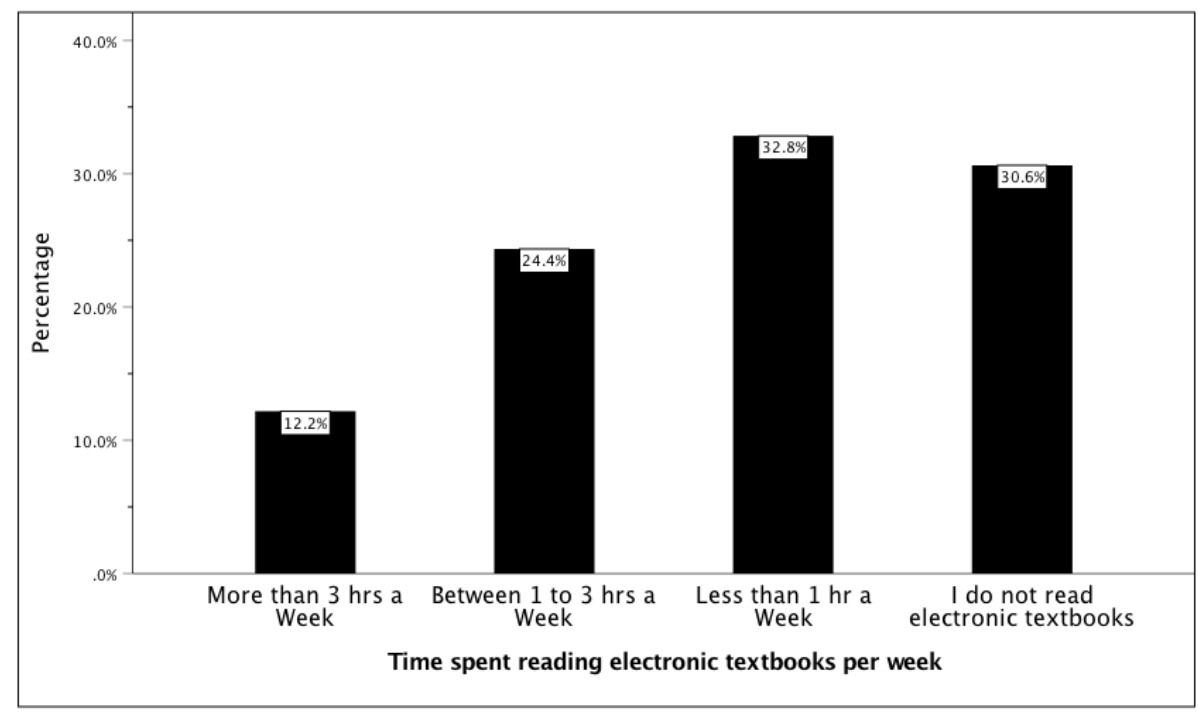

Fig. 4. Bar graph depicting Students' Responses to "How many hours a week do you usually spend reading your electronic textbooks?"

As shown, the results indicated that 66 students (around 24\%) were spending 1 to 3 hours a week reading their electronic textbooks. The results also showed that only 33 students (around 12\%) were spending more than 3 hours a week reading their electronic textbooks. However, it is worth to mention that 83 students (around 31\%) were not reading their electronic textbooks at all. 


\subsection{What is students' preference for textbook format?}

The third research question measured students' preference for textbook format in support of their studies. Results related to this question as obtained from the sample are presented in Table 6. The data from the table are displayed in a bar graph in Figure 5.

Table 6. Students' preference for textbook format

\begin{tabular}{|l|c|c|}
\hline & Frequency & Percent \\
\hline I prefer print textbooks over e-textbooks & 167 & 61.6 \\
\hline I prefer e-textbooks over print textbooks & 95 & 35.1 \\
\hline Undecided & 9 & 3.3 \\
\hline Total & $\mathbf{2 7 1}$ & $\mathbf{1 0 0 . 0}$ \\
\hline
\end{tabular}

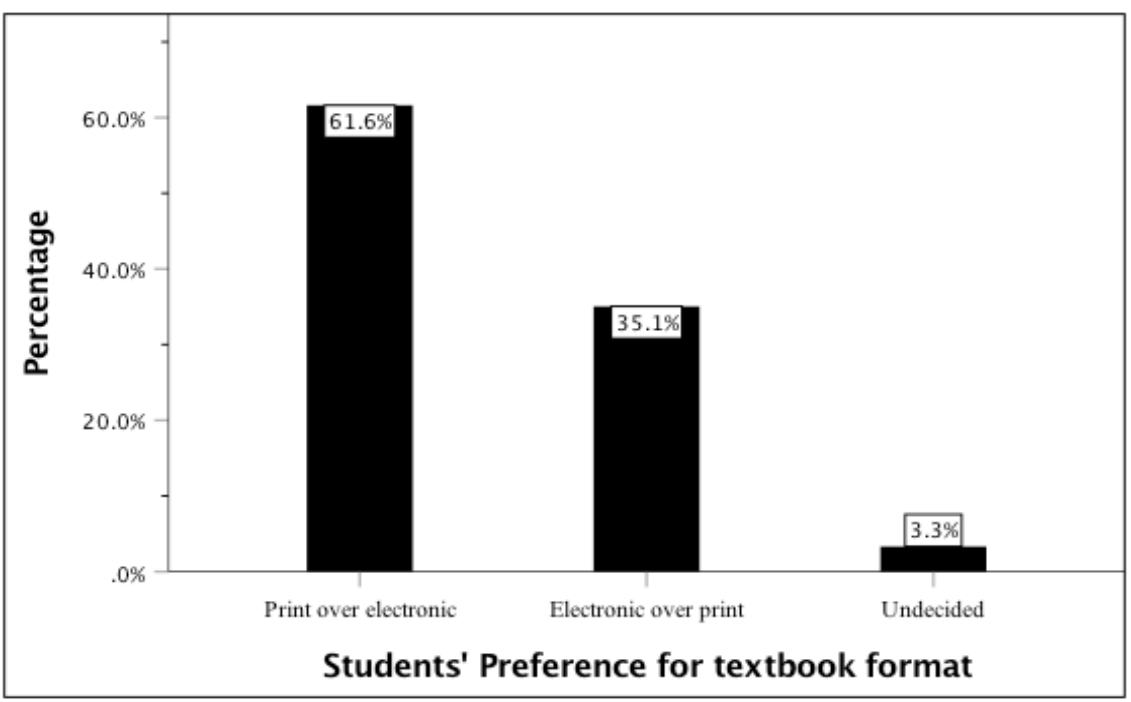

Fig. 5. Students' preference for textbook format

The above results showed that 167 students (around 62\%) preferred print textbooks over electronic textbooks. Around 31\% (95 students) preferred electronic textbooks over print textbooks. Interestingly, a $3.3 \%$ of the 271 students who participated in the study were undecided about their preference for textbook formats

\subsection{What are the reasons for students' preference of textbook format?}

The forth research question investigated the reasons for students' preference of textbook format. Students were asked to rate a list of potential reasons on a scale from 1 to 5 , with 1 as a "very weak reason", 2 as a "weak reason", 3 as a "moderate reason", 4 as a "strong reason", and 5 as "very strong reason". Table 7 presents, in a descending order, the reasons students rated for preferring print textbooks over e- 
textbooks. Students who responded to this list were those who clearly indicated their preference for print textbooks over e-textbooks as previously shown in Table 6. The top "strong" reasons, according to Table 7, for preferring print textbooks over etextbooks are: (1) Ease of use, (2) Readability, (3) Portability, and (4) Ease of highlighting and taking notes.

Table 7. Students' Reasons for Preferring Print Textbooks over e-Textbooks in a Descending Order $(n=167)$

\begin{tabular}{|c|l|c|c|c|c|}
\hline Rank & \multicolumn{1}{|c|}{ Reason } & Min & Max & Mean & Std. Dev. \\
\hline 1 & Ease of use & 1 & 5 & 4.48 & 1.352 \\
\hline 2 & Readability & 1 & 5 & 4.45 & 1.35 \\
\hline 3 & Portability & 1 & 5 & 4.35 & 1.467 \\
\hline 4 & Ease of highlighting and taking notes & 1 & 5 & 4.15 & 1.481 \\
\hline 5 & Effectiveness in memorizing information & 1 & 5 & 3.71 & 1.387 \\
\hline 6 & Ease of searching & 1 & 5 & 3.68 & 1.439 \\
\hline
\end{tabular}

On the other hand, Table 8 presents, in a descending order, the reasons students rated for their preference of e-textbooks over print textbooks. According to the table, the top "strong" reasons for preferring e-textbooks over print textbooks are:

- Ease of access

- Ease of searching

- Ease of navigation

Table 8. Students' Reasons for Preferring e-Textbooks over Print Textbooks in a Descending Order $(n=95)$

\begin{tabular}{|c|l|c|c|c|c|}
\hline Rank & \multicolumn{1}{|c|}{ Reason } & Min & Max & Mean & Std. Dev. \\
\hline 1 & Ease of access & 1 & 5 & 4.34 & 1.551 \\
\hline 2 & Ease of searching & 1 & 5 & 4.19 & 1.613 \\
\hline 3 & Ease of navigation & 1 & 5 & 4.15 & 1.657 \\
\hline 4 & Ease of archive & 1 & 5 & 3.62 & 1.53 \\
\hline 5 & Currency of information & 1 & 5 & 3.46 & 1.534 \\
\hline 6 & Cost saving (compared to print textbooks) & 1 & 5 & 3.10 & 1.629 \\
\hline
\end{tabular}

\section{Discussion and Conclusion}

This study came to explore college students' usage of and preference for print and electronic textbooks in a University college, Bahrain Teachers' College, in the Kingdom of Bahrain. The study surveyed 271 undergraduate students from courses that utilized both print and electronic textbooks. Students were selected based on gender, year of study, Cumulative Grade Point Average (CGPA), and specialization. Four research questions were formulated to help in conducting the study. These questions covered the frequency of using electronic and print textbook, the number of hours spent per week on reading these two formats of textbooks, students' preference for 
textbook format, and the reasons why students prefer one textbook format over the other.

On the frequency of using electronic and print textbooks, the results, shown in Figure 6 , revealed that almost half of the students $(56.8 \%)$ use their print textbooks only when required by the instructor. Interestingly enough, a closer percentage of students $(50.5 \%)$ reported the same frequency of use for their electronic textbooks. This concludes that regardless of textbook formats, the highest percentage of students use their textbooks only when their instructors require them to do so. Based on this finding, the researchers of this study emphasize the vital role of instructors in enhancing the use of textbooks (both electronic and print) among their students.

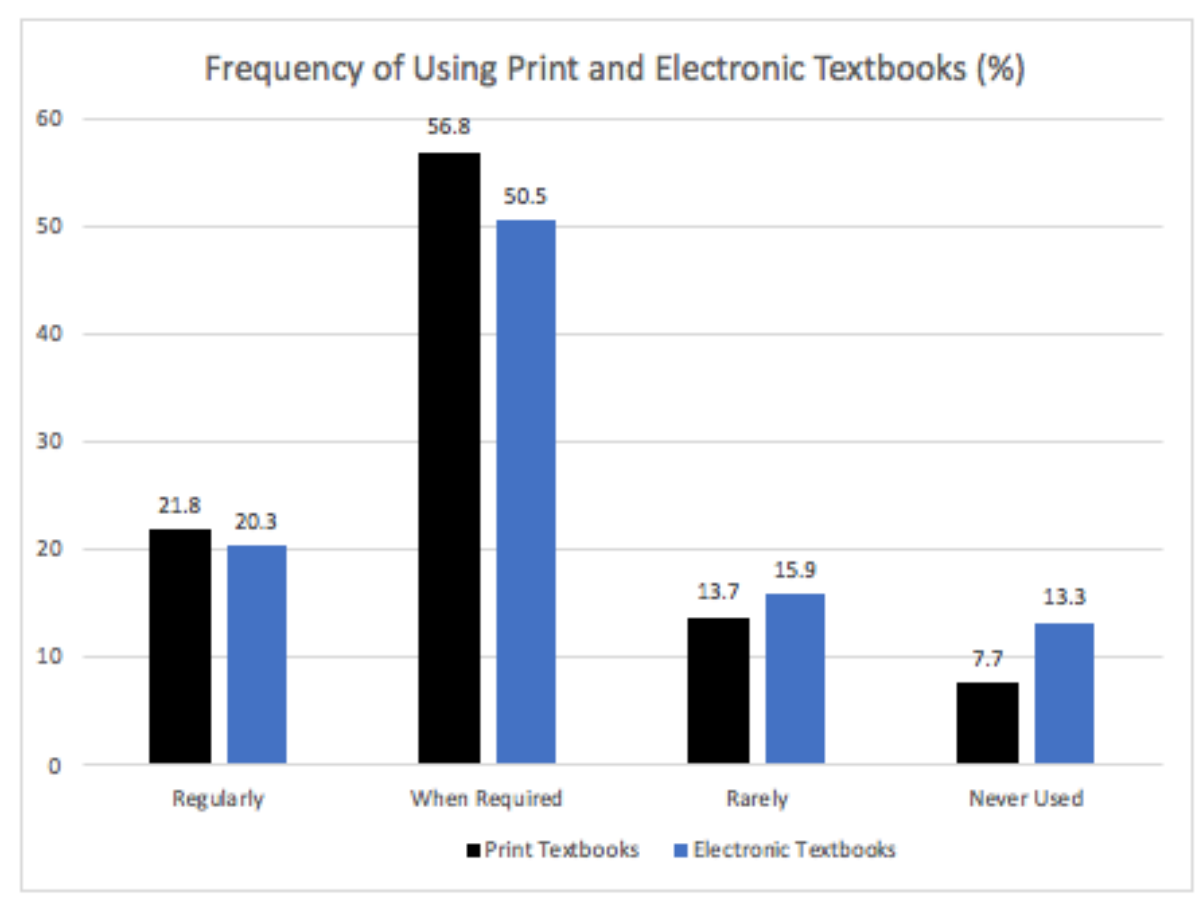

Fig. 6. Frequency of Using Print and Electronic Textbooks

Still on the frequency of use, the study manifested that print textbooks and electronic textbooks are "regularly" used by percentages of students of $21.8 \%$ and $20.3 \%$, respectively. Inspired by this result, the researchers strongly believe that being used regularly by almost one fifth of the study sample, electronic textbooks are making a tangible progress compared with print textbooks. The percentage of $20.3 \%$ is, in fact, double that obtained by Levine-Clark [31], who reported a percentage of $10 \%$ only. However, this result underlines the conclusion made by numerous research studies $[13 ; 27 ; 40 ; 53 ; 57 ; 45 ; 51]$, that electronic resources are gaining popularity in education. Taking this to a higher level, the researchers of this study recommend that more research be conducted on the issues related to the popularity of textbooks in educa- 
tion. For instance, a recent study conducted by Bouck et al. [7] indicated that the popularity of electronic textbook format will likely continue to grow as students get more exposure to the knowledge of its benefits in education. This, of course, emphasizes the importance of raising awareness of electronic study materials among students at all levels of education.

On the number of hours spent per week on reading textbooks, Figure 7 displays a comparison between print and electronic textbooks as reported by students. While $40.2 \%$ of students spend between 1 to 3 hours per week on reading their print textbooks, only $24.4 \%$ spend the same number of hours per week on reading their electronic textbooks. Conversely, while $25.5 \%$ spend less than 1 hour per week on reading their print textbooks, $32.8 \%$ spend the same number of hours per week on reading their electronic textbooks. Based on these results, it can be concluded that for print textbooks, the highest percentage of students (40.2\%) spend between 1 to 3 hours per week on reading. Whereas, for electronic textbooks, the highest percentage of students $(32.8 \%)$ spend less than 1 hour per week on reading.

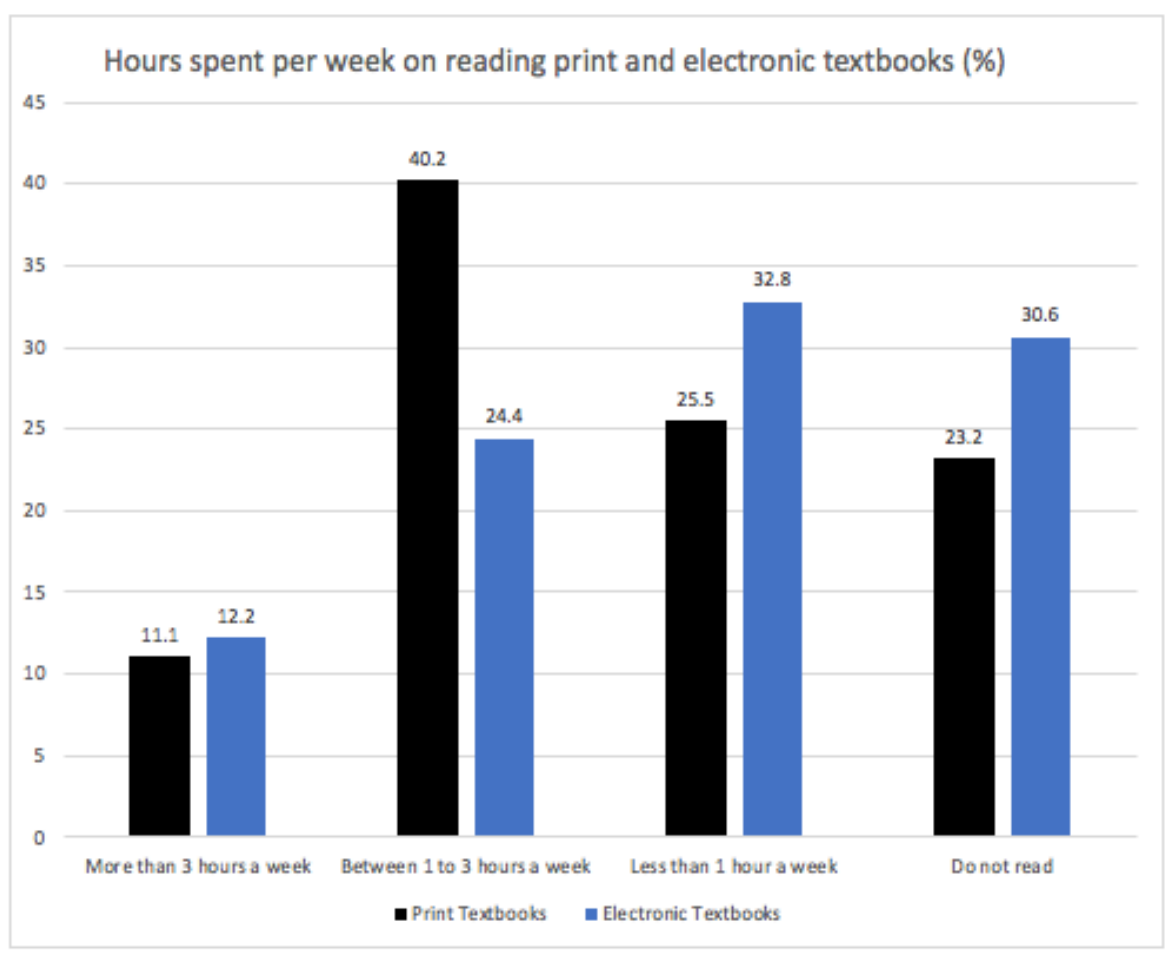

Fig. 7. Hours spent per week on Reading Print and Electronic Textbooks

A surprising finding to the researchers of the current study was the comparable percentage of students (i.e. 12.2\%) who spend more than 3 hours per week on reading electronic textbooks compared to that of students $(11.1 \%)$ who spend the same number of hours on reading print textbooks. This concludes that electronic textbooks win 
when it comes to spending higher numbers of hours of reading. In the researchers' opinion, although this percentage is relatively small, it can be considered fairly promising and is, therefore, worth obtaining more insight into its nature. For instance, Woody et al. [57] reported that students scan electronic text more than print text. They also noticed that students read electronic text, "searching for key terms rather than reading line by line" (p. 945). Therefore, it could be the "searching" capabilities of electronic text that encouraged students to spend more hours on reading their textbooks.

On students' preference for textbook format, the findings of the study revealed a clear preference for print over electronic. More specifically, while $61.1 \%$ of students prefer print textbooks over electronic, only $35.1 \%$ have the opposite preference. Based on this result and those of other studies $[3 ; 7 ; 27 ; 36 ; 46 ; 56]$, the researchers conclude that in spite of the growing popularity of electronic format in education, over half of college students still prefer print over electronic for their studies. In justifying this conclusion, the researchers believe that students' preferences between the two may not necessarily reflect their actual experiences but rather their familiarities with these formats. Therefore, this study conveys a message to policymakers, practitioners, and teachers to enhance and promote students' experiences with electronic textbooks.

Lastly, the study uncovered reasonable findings as to why students prefer one textbook format over the other. According to the findings, the top "strong" reasons for preferring print over electronic textbooks are ease of use, readability, portability, and ease of highlighting and taking notes. These reasons are similar to those found by Khalid [27] and Millar and Schrier [36]. It's worth to mention that these reasons came as no surprise to the researchers since they are the most cited advantages of the print format in literature. In other words, since print textbooks have been central for education for more than two centuries, their advantages and features are well-known for almost all learners.

Regarding why students prefer electronic over print textbooks, the findings of the study revealed the following "strong" reasons: ease of access, ease of searching, and ease of navigation. These reasons have been cited by a number of research studies, such as Abram [1], Cumaoglu et al. [11], Dillon [14], Khalid [27], Shelburne [44], and Sun et al. [50]. In the current study, it is interesting to notice that the top-rated reason for preferring electronic over print textbooks is ease of access. To the researchers, it seems that students were mostly inclined by the simplicity of accessing electronic textbooks. At the end of the day, an electronic textbook is just at the click of a button!

In conclusion, the study came to provide more insight on college students' usage and preference for print and electronic textbooks. The researchers believe that the findings of the study greatly helped in answering the main research questions. However, further investigations are needed to enable us to better understand the changing patterns of students' usage of print and electronic media in today's information-intensive environment. 


\section{Acknowledgement}

This study was supported by a research fund from the Deanship of Scientific Research (DSR) at the University of Bahrain, Kingdom of Bahrain. The authors would like to record their appreciation to all students of Bahrain Teachers' College who participated in the study.

\section{References}

[1] Abram, S. (2010). P-books vs e-books: death match? Information Outlook, 14(6), 30-32.

[2] Ackerman, R., Goldsmith, M. (2011). Metacognitive regulation of text learning: On screen versus on paper. Journal of Experimental Psychology: Applied, 7(1), 18-32. http://dx.doi.org/10.1037/a0022086

[3] Adeyinka, T., Dare, O., Adebisi, O., \& Lawal, A. (2018). Perception and Usage Pattern of e-books among Library and Information Science Students in Selected Universities in Nigeria. Journal of Library and Information Technology, 38(2), 132-140. http://dx.doi.org/10.14429/djlit.38.2.11111

[4] Anuadha, K. \& Usha, H. (2006). Use of e-books in an academic and research environment: a case study from the Indian Institute of Science. Program: electronic library and information systems, 40(1), 48-62. https://doi.org/10.1108/00330330610646807

[5] Baker-Eveleth, L. \& Stone, R. (2015) Usability, expectation, confirmation, and continuance intentions to use electronic textbooks. Behaviour \& Information Technology, 34:10, 992-1004. https://doi.org/10.1080/0144929X.2015.1039061

[6] Bierman, P. (2006). Reconsidering the Textbook. Carleton Education Website. Available online at: http://serc.carleton.edu/files/textbook/summary.pdf https://doi.org/10.1029/2006EO310004

[7] Bouck, E. C., Weng, P., \& Satsangi, R. (2016). Digital versus traditional: Secondary students with visual impairments' perceptions of a digital algebra textbook. Journal of Visual Impairment \& Blindness, 110(1), 41-52. https://doi.org/10.1177/0145482X1611000105

[8] Buzzetto-More, N., Sweat-Guy, R., \& Elobaid, M. (2007). Reading in a digital age: Ebooks are students ready for this learning object? Interdisciplinary Journal of Knowledge and Learning Objects, 3(1), 239-250. https://www.learntechlib.org/p/44809/ https://doi.org/10.28945/397

[9] Chiu, T. (2017). Introducing electronic textbooks as daily-use technology in schools: A top-down adoption process. British Journal of Educational Technology, 48(2), 524-537. https://doi.org/10.1111/bjet.12432

Choppin, J., Carson, C., Borys, Z., Cerosaletti, C., \& Gillis, R. (2014). A typology for analyzing digital curricula in mathematics education. International Journal of Education in Mathematics, Science and Technology, 2(1), 11-25. https://www.learntec hlib.org/p/157732/

[10] Cumaoglu, G., Sacici, E., \& Torun, K. (2013). E-Book versus Printed Materials: Preferences of University Students. Contemporary Educational Technology, 4(2), 121-135.

[11] DiGisi, L. L. \& Willett, J. B. (1995). What high school biology teachers say about their textbook use: a descriptive study? Journal of Research in Science Teaching, 32, 2, 123 142. http://dx.doi.org/10.1002/tea.3660320204

[12] deNoyelles, A. \& Raible, J. (2017). Exploring the Use of E-Textbooks in Higher Education: A Multiyear Study. EDUCAUSEreview. Available at: 
https://er.educause.edu/articles/2017/10/exploring-the-use-of-e-textbooks-in-highereducation-a-multiyear-study

[13] Dillon, D. (2001). E-books: The University of Texas experience, part 2. Library Hi Tech Journal, 19(4), 350-362. https://doi.org/10.1108/EUM0000000006540

[14] Dobler, E. (2015). E-textbooks. Journal of Adolescent \& Adult Literacy, 58(6), 482-491. https://doi.org/10.1002/jaal.391

[15] Foasberg, N. (2014). Student reading practices in print and electronic media. College and Research Libraries, 75(5), 705-723. https://doi.org/10.5860/crl.75.5.705

[16] Fouh, E., Karavirta, V., Breakiron, D. A., Hamouda, S., Hall, S., Naps, T. L. \& Shaffer, C. A. (2014). Design and architecture of an interactive eTextbook-The OpenDSA system. Science of Computer Programming, 88, 22-40. DOI: https://doi.org/10.5860/crl.75.5.705

[17] Gardiner, E. \& Musto, R. (2010). The Electronic Book. In Suarez, M. F., and H. R. Woudhuysen. The Oxford Companion to the Book. Oxford: Oxford University Press, p. 164.

[18] Gerhart, N., Peak, D., \& Prybutok, V. (2017). Encouraging E-Textbook Adoption: Merging Two Models. Decision Sciences Journal of Innovative Education, 15(2), 191-218. https://doi.org/10.1111/dsji.12126

[19] Gu, X., Wu, B. \& Xu, X. (2015). Design, development, and learning in e-Textbooks: what we learned and where we are going. Journal of Computers in Education, 2(1), 25-41. https://doi.org/10.1007/s40692-014-0023-9

[20] Gupta, S, \& Kumar, Sh. (2016). Preference and Usage of Print and E-Resources among Faculties and Students: A Study of Vasanta College for Women. In D. Kar, P Jain \& P. Babbar (Eds.), Leveraging the Digital Paradigm (pp. 31-35). SYNERGY BOOKS INDIA.

[21] Hendricks, D. (2017). Why Digital Publishing is the Future of Education. Inc.com. Available at: https://www.inc.com/drew-hendricks/why-digital-publishing-is-the-future-ofeducation.html

[22] Hill, R. 2010. Turning the page: Forget about those bulky backbreakers, digital textbooks are the future. School Library Journal, 56(10), 24-27.

[23] Horsley, M., Knight, B.A. \& Huntly, H. 2010. "The role of textbooks and other teaching and learning resources in higher education in Australia: Change and continuity in supporting learning". International Association for Research on Textbooks and Education (IARTEM) e-Journal, vol. 3, no. 2, pp. 43-61.

[24] Jabr, F. (2013). The Reading Brain in the Digital Age: The Science of Paper versus Screens. Scientific American. Retrieved from: https://www.scientificamerican.com/article/reading-paper-screens/

[25] Johnston, D., Berg, S., Pillon, K., Williams, M. (2015). Ease of use and usefulness as measures of student experience in a multi-platform e-textbook pilot. Library Hi Tech, 33(1), 65-82. http://scholar.uwindsor.ca/leddylibrarypub/33 https://doi.org/10.1108/LHT$\underline{11-2014-0107}$

[26] Khalid, A. (2014). Textbooks: e-book Vs. Print. Journal of Education and Human Development, 3(2), 243-258.

[27] Kouis, D. \& Konstantinou, N. (2014). Electronic textbooks advantages and challenges for the Hellenic higher education and publishing community, Library Review, 63(6/7), 531543. https://doi.org/10.1108/LR-06-2014-0074

[28] Landoni, M. \& Diaz, P. (2003). E-education: Design and Evaluation for Teaching and Learning. Journal of Digital Information. 3(4). Available online at: https://journals.tdl.org/jodi/index.php/jodi/article/view/118/85 
[29] Lee, H. J., Messom, C., \& Yau, K. A. (2013). Can an electronic textbook be part of K-12 education? Challenges, technological solutions and open issues. Turkish Online Journal of Educational Technology - TOJET, 12(1), 32-44.

[30] Levine-Clark, M. (2006). Electronic book usage: a survey at the University of Denver. Portal: Libraries and the Academy, 6(3), 285-99. https://doi.org/10.1108/01604950710721548

[31] Mangen, A., Walgermo, B., \& Brønnick, K. (2013). Reading linear texts on paper versus computer screen: Effects on reading comprehension. International Journal of Educational Research, 58, 61-68. https://doi.org/10.1016/j.ijer.2012.12.002

[32] Marques, S. (2012). e-Textbooks Usage by Students at Andrews University: A Study of Attitudes, Perceptions, and Behaviors. Proceedings of the IATUL Conferences. Paper 32. Available online at: https://docs.lib.purdue.edu/iatul/2012/papers/32/

[33] McFall, R. (2005). Electronic textbooks that transform how textbooks are used. The Electronic Library, 23, 1, 72-81. https://doi.org/10.1108/02640470510582754

[34] McGowan, M. K., Stephen, P. R., \& Bradley, C. W. (2009). Student perceptions of electronic textbooks. Issues in Information Systems, 10(2), 459-465.

[35] Millar, M., \& Schrier, T. (2015). Digital or printed textbooks: Which do students prefer and why? Journal of Teaching in Travel \& Tourism, 15(2), 166-185. https://doi.org/10.1080/15313220.2015.1026474

[36] Mulholland, E., \& Bates, J. (2014). Use and perceptions of E-books by academic staff in further education. Journal of Academic Librarianship, 40(5), 492-499. https://doi.org/10.1016/j.acalib.2014.05.018

[37] Nariani, R. (2009). E-books in the sciences: if we buy it will they use it? Issues in Science and Technology Librarianship, DOI: 10.5062/F4WS8R5G. Available online at: www.istl.org/09-fall/article3.html

[38] Nelson, M. R. (2008). E-books in higher education: Nearing the end of the era of hype? EDUCAUSE Review, 43(2), 40-56.

[39] Nicholas, D., Rowlands, I., Jamali, H.R., Clark, D., Huntington, P. and Olle, C. (2008). UK scholarly e-book usage: a landmark survey. Aslib Proceedings, 60(4), 311-34. https://doi.org/10.1108/00012530810887962

[40] Picardo, J. (2016). Using Technology in the Classroom. Bloomsbury CPD Library. London, UK.

[41] Rowlands, I., Nicholas, D., Jamali, H.R. and Huntington, P. (2007). What do faculty and students really think about e-books. Aslib Proceedings, 59(6), 489-511. https://doi.org/10.1108/00012530710839588

Rockinson-Szapkiw, A. J., Courduff, J., Carter, K., \& Bennett, D. (2013). Electronic versus traditional print textbooks: A comparison study on the influence of university students' learning. Computers \& Education, 63, 259-266. https://doi.org/10.1016/j.compedu.2012.11.022

[42] Shelburne, W. (2009). E-book usage in an academic library: user attitudes and behaviors. Library Collections, Acquisitions, \& Technical Services, 33(2/3), 59-72. https://doi.org/10.1080/14649055.2009.10766234

[43] Shepperd, J., Grace, J., and Koch, E. (2008). Evaluating the electronic textbook: is it time to dispense with the paper text? Teaching of Psychology, 35, 2-5. https://doi.org/10.1080/00986280701818532

[44] Shin, S. (2014). E-book usability in educational technology classes: Teachers and teacher candidates' perception toward e-book for teaching and learning. International Journal of Distance Education Technologies, 12(3), 62-74. https://doi.org/10.4018/ijdet.2014070105 
[45] Simon, J., \& Garcia-Belmar, A. (2016). Education and Textbooks. Technology and Culture, 57(4), 940-950. https://doi.org/10.1353/tech.2016.0114

[46] Stein, M., Remillard, J., \& Smith, M. 2007. How curriculum influences students' learning. In Lester F., Second handbook of research on mathematics teaching and learning (pp. 557628). Information Age, Charlotte, NC.

[47] Stone, R. W., \& Baker-Eveleth, L. J. (2013). Students' intentions to purchase electronic textbooks. Journal of Computing in Higher Education, 25(1), 27-47. https://www.learntechlib.org/p/113875/ https://doi.org/10.1007/s12528-013-9065-7

[48] Sun, J., Flores, J. and Tanguma, J. (2012). E-textbooks and students' learning experiences. Decision Sciences Journal of Innovative Education, 10(1), 63-77. https://doi.org/10.1111/j.1540-4609.2011.00329.x

[49] Tees, T. (2010). Ereaders in academic libraries: a literature review. Australian Library Journal, 59(4), 180-186. https://doi.org/10.1080/00049670.2010.10736023

[50] UNESCO 2016. Every Child Should Have a Textbook. Policy Paper 23. Global Education Monitoring Report. Paris, France.

[51] Walton, E. (2014). Why undergraduate students choose to use e-books. Journal of Librarianship and Information Science, 46(4) 263-270. https://doi.org/10.1177/0961000613488124

[52] Wang, W. C., Lin, C. H. \& Lee, C. C. (2011). Thinking of the textbook in the ESL/EFL classroom. English Language Teaching, 4, 2, 91-96. DOI:10.5539/elt.v4n2p91 https://doi.org/10.5539/elt.v4n2p91

[53] Wang, J. (2018). Retrieving critical design factor of ebook for older people in Taiwan. Telematics and Informatics, 35(7), 2016-2027. https://doi.org/10.1016/j.tele.2018.07.005

[54] Wiese, M., \& du Plessis, G. (2014). The battle of the e-textbook: Libraries' role in facilitating student acceptance and use of e-textbooks. South African Journal of Libraries \& Information Science, 80(2), 17-26. https://doi.org/10.7553/80-2-1509

[55] Woody, W., Daniel, U., and Baker, C. (2010). E-books or textbooks: student prefer textbooks. Computer Education, 55, 945-948. https://doi.org/10.1016/j.compedu.2010.04.005

\section{$7 \quad$ Authors}

Amjad M. Abuloum is an associate professor of Instructional Technology in the Math and Science Department at Bahrain Teachers' College, University of Bahrain. For several years, he served as the Director of Learning Resources and Information Technology in the college.

Adnan Farah is a professor of Counseling Psychology at Bahrain Teachers' College, University of Bahrain. He is the Editor-in-Chief and Founding Editor of the International Journal of Research in Education \& Psychology.

Esra Kaskaloglu is an assistant professor at Bahrain Teachers' College, University of Bahrain. She served as the Director of Quality Assurance and Strategic Planning in the college.

Abduyah Yaakub is an assistant professor of Educational Psychology at Bahrain Teachers' College, University of Bahrain.

Article submitted 2018-11-17. Resubmitted 2018-12-15. Final acceptance 2018-12-15. Final version published as submitted by the authors. 